Article

\title{
An Imperfect Firewall: Quebec's Constitutional Right of Secession as a Device Against Domination
}

\author{
Lluís Pérez-Lozano \\ Department of Political and Social Sciences, Pompeu Fabra University, Spain; E-Mail: Iluis.perezlozano@upf.edu
}

Submitted: 29 May 2021 | Accepted: 27 July 2021 | Published: 10 December 2021

\begin{abstract}
The idea of including a right of secession in democratic constitutions has been discussed by different political and legal theorists; however, little has been said on the matter from the point of view of democratic-republican political philosophy. This article undertakes this effort by means of a normative analysis of Quebec's constitutional right of secession, as outlined in the Quebec Secession Reference. This analysis shows how the non-unilateral nature of this right minimises the risks for republican freedom (as non-domination) and inclusion in the Quebec secession conflict, while the fact that it is limited to a national constitutional framework dampens this achievement.
\end{abstract}

\section{Keywords}

Canada; constitutionalism; democracy; domination; factions; Quebec; republicanism; secession

\section{Issue}

This article is part of the issue "Secessionism in Liberal Democracies: What Do We Really Know About the Explanations of Secessionism?" edited by Ferran Requejo (Pompeu Fabra University, Spain) and Marc Sanjaume-Calvet (Pompeu Fabra University, Spain / Open University of Catalonia, Spain).

(C) 2021 by the author; licensee Cogitatio (Lisbon, Portugal). This article is licensed under a Creative Commons Attribution 4.0 International License (CC BY).

\section{Introduction}

The possibility of a constitutional right of secession in modern democracies has attracted the attention of different scholars, either to endorse it (Corlett, 1998; Jovanovic, 2007; Norman, 2003; Weinstock, 2000, 2001) or to reject it (Aronovitch, 2006; Sunstein, 1991, 2001), but up until now little analysis on the matter has been done from the point of view of democratic-republican political philosophy. This article undertakes this analysis by trying to answer one question: To what extent can a constitutional right of secession be useful in order to minimise exclusion and domination (understood in democratic-republican terms) stemming from secession political conflict in modern democracies? My answer is built upon a normative analysis of the case of Quebec, which in 1998 was granted a (quasi) constitutional right of secession by the Supreme Court of Canada.

To sum up, I think that secession conflicts must be understood as the ultimate expression of centreperiphery conflict, in which permanent majorities and permanent minorities disagree and fight over how the state should be conceived and organised in terms of economy, territory, and identity. These political conflicts imply a series of threats concerning exclusion and domination, and the case of Quebec shows us that a constitutional right of secession can act as a firewall against them due to its non-unilateral nature, which largely avoids intractable debate on who is the sovereign over the territory inhabited by the permanent minority. However, constitutions do not discuss who the sovereign is, but take it for granted, and this weakens the capability of a constitutional right of secession to minimise exclusion and domination.

I will present this analysis in the following five sections: an outline of the theoretical and methodological framework employed; a description both of the Quebec Secession Reference (here also referred to by Reference) and the constitutional right of secession it outlines; an account of its strengths in terms of minimising domination and exclusion in the Quebec secession conflict; a critique in the opposite direction, highlighting the unresolved issues that undermine its strengths, 
and particularly of the Reference's failure to designate an arbiter for a potential non-unilateral secession process; and a summary of my conclusions.

\section{Theoretical and Methodological Framework}

As with any other tradition of political thought, there is not a single and univocal understanding of republicanism. This article is based on the contemporary reconstruction of the republican tradition developed by authors like Pettit (1997) or Bellamy (2007) upon the historical work of Skinner (1998), arguably the mainstream in current republican literature. According to these scholars, republicanism (a) stands for freedom as non-domination; (b) understands domination as the power of $X$ to exercise arbitrary interference over $\mathrm{Y}$; (c) argues that, in order to promote republican freedom, private sources of power must be controlled and dispersed by the state; (d) argues that, in order to prevent the state of becoming itself a dominator, it must be organised as a constitutional self-governing political community, with its own powers being dispersed, prevented to be monopolised by any faction, and kept in check by civic virtue and the rule of law; and (e) argues that civic virtue and freedom are mutually dependent. Besides, democratic republicans, as opposed to oligarchic ones, seek republican freedom to include as many people as possible. Thus, domination and exclusion, so defined, are the main concerns of democratic republicanism.

Republicanism so considered encompasses authors like Aristotle, Cicero, Machiavelli, Spinoza, Madison, or Wollstonecraft, to name but a few. For all these thinkers, one of the key elements, in order to design political institutions, was their ability to manage political conflicts so that none of the contending factions could win an absolute (and, therefore, arbitrary) power over the others. However, republicanism has given little attention to design institutions able to manage a type of political conflict in which the contending factions seek neither to win power within a state nor to win power for a state, but either to become a state out of another one (secessionism) or to prevent someone from doing so (unionism). That is: secession conflicts.

In my view (Pérez-Lozano, 2021, pp. 28-32), these political conflicts may imply four different threats in democratic republican terms: (a) exclusion, as some people who would be directly affected by secession may be excluded from deciding on it (for example, an ethnic minority within the seceding territory); (b) domination by blackmailing minorities, as in case they were entitled to secession, powerful minorities (for example, wealthy ones) could be able to blackmail the rest of the polity; (c) domination by arbitrary permanent majorities, as secession conflicts are usually the ultimate expression of particularly deep centre-periphery political conflicts, in which the centre and a given regional periphery of the state are politically hegemonised, respectively, by a permanent majority and a permanent minority, both of them defined along permanent disagreements on how the state should be conceived and organised in terms of economy, territory, and identity (Rokkan \& Urwin, 1983) so that without a feasible exit option, permanent minorities would be at mercy of arbitrary permanent majorities; and (d) instability, that is, the risk that a bad handling of secession conflicts, and even the absence of any handling at all, is likely to promote instability, eventually triggering exclusion and/or domination.

I think that a democratic republican theory of right of secession, able to overcome those threats, must pay particular attention to the possibility of designing non-unilateral mechanisms for secessionists and unionists to pursue their goals. This requires us to outline how a balanced negotiation framework for secession conflicts could look. Unlike most scholars (Buchanan, 2007, pp. 338-339), I don't regard "constitutional" and "non-unilateral" as necessarily synonymous; however, it is clear that exploring the possibility of a constitutional right of secession is a good place to start this effort. This article undertakes this exploration through a case study: Quebec's (quasi) constitutional right of secession as sketched in the Quebec Secession Reference by the Supreme Court of Canada.

This is not a causal or a descriptive, but a normative, case study (Bauböck, 2008, pp. 56-57): My aim has not been to get descriptions or to infer causal explanations, but rather to analyse the compliance between an institutional device (Quebec's constitutional right of secession) and a normative approach (democratic republicanism), in order to draw lessons for the management of a type of political conflict (secession conflicts) in a broader number of cases (modern democracies) from the point of view of that approach. Here arise, however, two methodological questions: Why this focus on modern democracies, instead of also examining the constitutional right of secession in authoritarian contexts? Why give primacy to Quebec over other cases of constitutional right of secession in modern democracies?

In both questions, the answer has to do with a concern for minimising what we may call "normative noise," that is, those normative issues that distract our attention from the ones that we wanted to discuss in the first place. In order to use cases of constitutional right of secession to evaluate its usefulness for democratic-republican purposes, the absence of democracy is one of the most disturbing sources of normative noise. In our days, modern democracies are the closest polities to democraticrepublican ideals, however imperfectly. The usefulness of a constitutional right of secession for democraticrepublican purposes will therefore be better analysed by focusing on modern democracies than on authoritarian regimes. It is when someone seeks to create a modern democratic state out of the territory of another one that we find the tricky questions for democratic republicanism.

On the same grounds of minimising normative noise, I decided to sidestep those cases of constitutional right of secession in democratic contexts in which, until 
very recently, violence has played a prominent role in the secession conflict (Northern Ireland, Serbia, and Montenegro) or size and geography make it quite problematic to extrapolate results to the bulk of modern democracies (St. Kitts and Nevis, Liechtenstein). I also considered it better to discard: Scotland and Bougainville, since what we find there is not a constitutional right of secession as such, but rather an ad hoc agreement between secessionists and the central government that, constitutionally speaking, relies on the good faith of the latter; Norway, Iceland, and Puerto Rico, since in these cases the seceding or potentially seceding territory was not exactly integrated into the host state, but rather formed a quasi-sovereign unit under the umbrella of a larger, associated sovereign state; and Ethiopia, since it is far from being a functioning and stable modern democracy, having become a hegemonic party system following the categorisation of Sartori (2005).

Quebec, in contrast, does not present these problematic features. The only serious struggle for violent secessionism, led by the far-left Front de libération du Québec, only lasted for about seven years, indeed before Quebec secessionism actually became a major political force with real political power. Quebec's size and geography are fairly comparable to other major potentially secessionist territories, such as Scotland, Catalonia, the Basque Country, or Flanders. Its constitutional right of secession is implicitly recognised in a judicial Reference, which actually imposes obligations on the federal government on that score. It is not a colony, nor an associated state, but an integral part of the sovereign state of Canada. Moreover, both Quebec and Canada are stable and wellfunctioning modern democracies. Upon these considerations, I have built my normative analysis of Quebec's constitutional right of secession, which I develop in the following four sections.

\section{Context and Content of the Quebec Secession Reference}

The narrow margin of the "No" victory in the 1995 Quebec sovereignty referendum triggered the debate of what would have happened in the event of a "Yes" victory. According to Dion (1995), the positions in this debate could be divided between two broad groups: impossibilists (for whom Quebec's secession would have been impossible, even in the event of a "Yes" victory) and inevitabilitists (for whom Quebec's secession would have been rendered inevitable by a "Yes" victory). As Dion recalls, both inevitabilitists and impossibilists assumed that a "Yes" victory would have opened a period of economic and political uncertainty. However, while impossibilists focused on the effects that such uncertainty would have had over Quebec, inevitabilitists' attention was mainly on the effects that it would have had over the rest of Canada (ROC).

It was due to this uncertainty that the federal government submitted the request of an advisory opinion of the Supreme Court on the following three questions: (a) Under the Constitution of Canada, can the National Assembly (that is, Quebec's parliament), legislature, or government of Quebec effect the secession of Quebec from Canada unilaterally? (b) Does international law give the National Assembly, legislature, or government of Quebec the right to effect the secession of Quebec from Canada unilaterally? In this regard, is there a right to self-determination under international law that would give the National Assembly, legislature, or government of Quebec the right to effect the secession of Quebec from Canada unilaterally? (c) In the event that there were a conflict between domestic and international law on the right of the National Assembly, legislature, or government of Quebec to effect its secession from Canada unilaterally, which would take precedence in Canada?

In a book written shortly before the release of the Quebec Secession Reference, and published shortly after, Young (1999, p. 127) affirmed that there was "no doubt this will be a carefully written and nuanced judgment, but it will very likely state that secession is illegal under domestic law unless accomplished through an amendment of the Canadian constitution." Sovereigntists denied the legitimacy of the Court to rule on the matter, accusing the Court of having a profederalist bias and asserting that Quebecers, as a people, had an inalienable right to decide their own future (Sauvageau et al., 2005, pp. 105-107).

To the surprise of many, but as some keen commentators predicted (Sauvageau et al., 2005, p. 113), the Reference eventually appeared not to be the definitive constitutional blow against sovereigntism that Ottawa sought, and the sovereigntists feared. Certainly, the Court denied Quebec the right of unilateral secession either under constitutional or under international law; and since no conflict was seen between those two legal bodies, the Court deemed it unnecessary to answer the third question. The originality of the Reference was due to the fact that, in addition to it denying Quebec's right to secede unilaterally, it also denied Ottawa (and the other provinces) the right to unilaterally ignore a democratic secessionist will, expressed by a clear majority of Quebecers in front of a clear question on secession. A clear "Yes" victory should be followed, according to the Reference, by negotiations in good faith between Quebec and the ROC, in order to reach an agreement; an agreement which could naturally include secession, although the Reference did not clearly specify whether secession was just a possibility or an almost certain outcome of that negotiation (as I will discuss in the fifth section of this article).

The Court derived this conclusion from its reading of the Canadian constitution as based on the (interdependent) principles of federalism, democracy, constitutionalism, the rule of law, and protection of minorities. Thus, the Court expelled the unilateralist positions of both sides from the field of what was constitutionally acceptable while outlining an arena in which the reasonable 
aspirations of both parties could be expressed and pursued by peaceful and democratic means and, in the end, negotiated with the other party. According to Requejo (2005, p. 60), this was tantamount to "recognising the legitimacy of the right to self-determination for the peoples of a multinational federation," but regulating it "from a federal rather than from a nationalist perspective."

As Young (1998, p. 15) said, the Reference "delivered something to each side," and it was indeed "hailed as a victory by both federal government and Quebec government representatives alike" (Woehrling, 2000, p. 93); thus, the Supreme Court gained legitimacy as an impartial actor among initially reluctant Quebec sovereigntists, while maintaining its legitimacy among federalists who would have been disappointed by an excessively generous stance towards secessionists. The Reference can therefore be described as balanced and moderate, having given Quebec a (quasi) constitutional right of secession. Now, the question is to what extent is this constitutional right of secession, as outlined in the Quebec Secession Reference, a useful device to overcome the four threats to democratic-republican goals that we have seen linked to secession conflicts.

\section{A Firewall Against Domination and Exclusion}

We have no reason to think that the judges of the Supreme Court of Canada had republicanism in mind when they delivered the Quebec Secession Reference. However, the democratic-republican goals of minimising domination and exclusion are largely in tune with the idea of the Canadian constitution being based on an interdependent relationship between the principles of federalism, democracy, constitutionalism, the rule of law, and protection of minorities. As Schertzer (2016, pp. 139-168) states, the Reference outlines an understanding of the Canadian federation as the process and outcome of negotiation between different legitimate models of such federation, instead of imposing one of them; an understanding which, as Schertzer (2016, p. 83) points out, is in line with republican principles concerned with reducing domination. Following this reading of the Reference, we can ask whether the constitutional framework outlined for the Quebec secession conflict is a good firewall against the four threats mentioned in the second section.

The threat which is most obviously confronted by the Reference is the threat of instability. The Quebec Secession Reference provides an answer to what would (or, at least, legally should) happen after a "Yes" victory: a process of negotiation in good faith between two distinct democratic majorities. As we will see in the next section, this solution is not problem-free; however, it is a step beyond the pre-Reference situation. On the other hand, concerning the threat of blackmailing minorities, the Reference plainly addresses it by forbidding Quebec's right to secede unilaterally, which obviously undermines
Quebec's capacity to blackmail the ROC by recurring to the threat of secession. If secession were to occur, it would have to be through negotiation conducted in good faith by both parties.

Concerning the threat of exclusion, the Reference implicitly addresses it in different ways. On the one hand, it points out an affirmative vote by "a clear majority of Quebecers" to a "clear question on secession" as the basic element that would create an obligation for Ottawa to negotiate with Quebec. Since the Court does not seem to equate "Quebecers" to "Francophone Quebecers," it seems to avoid any of the would-be residents of the independent country being excluded from the vote. Besides, the Court explicitly includes the aboriginal interests among those that should be considered during negotiations (Supreme Court of Canada, 1998, pp. 269, 288). Again, these provisions are not problemfree, but they are better placed to confront exclusion than the pre-Reference situation.

However, where the Quebec Secession Reference is most innovative is, in my view, when it comes to confronting the threat of arbitrary permanent majorities. In case of a "Yes" victory, without the Reference imposing an obligation to negotiate on Ottawa, the actual opening of those negotiations would have depended on the goodwill of Ottawa's federalists. Moreover, even if Ottawa were to open such negotiations, it would have been in Ottawa's hands, legally speaking, to end them whenever it wanted. That is: Ottawa would have had arbitrary power to deal with this conflict in the manner that it considered appropriate.

Take, for instance, the case of the two Quebec referenda: During each campaign, Canadian Prime Ministers Pierre Trudeau and Jean Chrétien, both explicitly opposed to moderate Quebec nationalists' goals (such as giving Quebec special powers), made nevertheless imprecise promises of building "a new Canada," thus assuring that a "No" vote was not a vote for the status quo of the Quebec-Canada relationship. Whether or not those promises were fulfilled in the eyes of most Quebec nationalists is quite another thing (and clearly, it was not the case of Trudeau's 1982 constitutional patriation), but it is reasonable to assume that such promises would never have been made without the threat of Quebec leaving Canada.

Had the Court plainly denied Quebec any right of secession, there is no reason to think that Ottawa would have started to behave as an oppressive, uniformistic, or centralistic government. But it is reasonable to assume that any new constitutional negotiation on the status of Quebec within Canada would have been conducted from the perspective that, in the end, Quebec would have had no option but to take what Ottawa was willing to give, or to leave empty-handed. That is, in the conflict between the permanent minority of Quebec nationalists (a permanent majority in Quebec) and the permanent majority of Pan-Canadian nationalists in the ROC on how to organise economy, territory, and identity in Quebec and 
Canada, Pan-Canadian nationalists would have, to a large extent, dominated the Quebec nationalists. And the normal devices of modern democracies that are seen as protecting people from domination (separation of powers, the rule of law, universal suffrage, free elections, multi-party competition, individual rights, even federalism) would have left this unequal relationship largely untouched. This is what the threat of arbitrary permanent majorities looks like.

On the other hand, had the Court plainly asserted that Quebec had the right to secede unilaterally, a relationship involving domination could have emerged in the opposite direction due to the threat of blackmailing minorities. Moreover, had the Court refrained from ruling on the issue, the threat of instability (and, hence, of a "might makes right" scenario) would have been left in place. By forbidding each side of the conflict to pursue its goals without taking into account the interests and views of the other, the Quebec Secession Reference minimised the chances of any side dominating the other one. And, provided that this framework, so interpreted, appears to be fair and reasonable to both sides, it would be difficult for any of them to break from it unilaterally whilst also appearing as a reasonable and fair player in the face of public opinion, either domestic or international-making it costly in terms of political legitimacy, as briefly pointed out in the Reference itself (Supreme Court of Canada, 1998, pp. 272-273).

Thus, it seems that the Reference, and the constitutional right of secession it outlines, acts as a firewall against exclusion, domination, and instability in the Quebec secession conflict and, broadly speaking, in the Quebec-ROC conflict on the definition of Canada in terms of economy, territory, and identity. However, the Reference left an important number of issues open and unresolved due, not to negligence by the Court, but to its explicit intention to refrain from playing a political role in the conflict, preferring only to define the general limits and rules that the political actors should observe within the Canadian constitution. Those unresolved issues are cracks in the anti-domination firewall raised by the Court which this article will outline in the following section.

\section{Cracks in the Firewall: The Unresolved Issues of the Quebec Secession Reference}

There are at least six great unresolved issues in the Quebec Secession Reference: (a) lack of clarity in concluding whether Quebec has a constitutional right of secession or not; (b) what constitutes a clear question; (c) what constitutes a clear majority; (d) what should be considered as "good faith" by the actors during a negotiation after a "Yes" victory in Quebec; (e) would Quebec retain its current borders in the event of secession; and (f) who would be the arbiter of the whole process. As we will see, the final question is the main crack the Reference reveals when assessed as a firewall against domination.
Concerning the first unresolved issue, we should notice that the Quebec Secession Reference, while typically considered as recognising a (quasi) constitutional right of secession for Quebec (Buchanan, 2007, p. 338; Norman, 2006, pp. 176-177; Weinstock, 2001, pp. 195-196), nevertheless contains some assertions that could blur this point. It says that it would be mistaken to consider that, in case of a "Yes" victory in a Quebec secession referendum, the ROC would have no choice but to negotiate the logistical aspects of secession (Supreme Court of Canada, 1998, p. 266); negotiations should follow, and secession should be considered as an option, but it should not be a necessary outcome. However, other parts of the Reference seem to imply a stronger obligation by the ROC to negotiate secession in the event of a "Yes" victory: "The negotiations that followed such a vote would address the potential act of secession, as well as its possible terms, should in fact secession proceed" (Supreme Court of Canada, 1998, p. 294).

A second unresolved issue is the clarity of the question in a referendum on secession. Though unresolved, it is relatively uncontroversial, at least theoretically: It is easy to see that the questions of the two Quebec referenda were at least complex. They contained 108 and 48 words, respectively, and they did not ask about independence as such, but about an agreement giving "sovereignty" to Quebec while remaining in some sort of economic association or partnership with Canada. While, on the other hand, the question asked in the recent Scottish referendum on independence was quite clear and simple: It contained six words, and it directly asked about Scottish independence. Nevertheless, it is still controversial to determine who should, in practice, be the judge of clarity.

More controversial is, of course, the third unresolved issue: What is a clear majority? This has a quantitative dimension and a qualitative one. Quantitatively, it has to do with the percentage of the "Yes" vote that would be considered as "clearly" forming a majority, either over the electorate or over the voters (that is, taking or not taking into account the turnout). Quebec secessionists tend to favour a lower threshold (normally fifty-plus-one of the voters), while federalists tend to favour a higher threshold. The qualitative issue is even more problematic: should a quantitative majority of all Quebecers (even a qualified majority) be enough to consider the "Yes" as a clear winner? Or, considering the demographic composition of Quebec (with Anglophone and Aboriginal minorities, normally opposed to independence), should we also require a certain percentage of non-Francophone minorities to support secession? And what if such percentages were not reached but the majority of Quebecers who favoured secession (regardless of their ethnic or linguistic affiliation) was actually huge?

A fourth unresolved issue has to do with the nature of negotiations. As we have seen, the Reference implies 
that, should one of the actors reject negotiations, it will be breaking its constitutional obligations under a fair and reasonable interpretation of the constitution, thus incurring huge costs in terms of legitimacy, both domestically and internationally. However, there are many ways of rejecting a negotiation while apparently trying to negotiate: one can, typically, put on the table a number of unreasonable demands as "unwaivable" knowing that the other side will never accept them (for example, concerning the share of the national debt that each side should assume). This is the reason why, in case of a clear "Yes" victory, the Reference imposes on both sides the obligation of negotiating "in good faith." However, who is the judge of "good faith"? Who decides which demands are "reasonable" and which are not? And what if negotiations happened to fail? Would any of the actors, in that case, have the right to pursue its agenda unilaterally?

A fifth unresolved issue is linked to the qualitative dimension of the definition of a clear majority: Would Quebec retain its current borders after secession? This is known as the debate on the partition of Quebec. The point of view of the partitionists was famously summed up by Pierre Trudeau: "If Canada is divisible, Quebec should be divisible too" (as cited in Shaw \& Albert, 1980, p. 16). This means that if a majority of Quebecers favouring secession from Canada is enough to justify secession, then a majority of inhabitants of any part of Quebec can also invoke the same principle in order to secede from Quebec and thus remain within Canada. However, suppose Quebec were divisible because Canada were divisible. In that case, it follows that Quebec would be divisible under the same terms as Canada: For instance, in the Aboriginal-populated lands of Northern Quebec, there should be a clear majority of Northern Quebecers (whether Aboriginal or not) answering "Yes" to a clear question on secession of Northern Quebec from the rest of the province; and after that "Yes" victory, then negotiations should follow between Quebec and Northern Quebec (and the ROC?). And, interestingly, we would find that if Quebec were divisible under the same terms as Canada, then Northern Quebec would be divisible under the same terms as Canada and Quebec.

Here, a prudent point of view could regard all this as the demonstration of one of the evils that a too permissive approach to secession is expected to promote: secession ad infinitum. Or, as it is sometimes known, Balkanisation. However, we have reasons to consider this an unlikely risk: People tend to be risk-averse, and there is evidence showing that only a limited range of groups with some sort of "ethnic" or "national" identity show a relevant share of its members as supporting secession (Sorens, 2012, pp. 52-56). Indeed, there is also some evidence that the existence of a legal path towards secession tends to favour the peaceful and stable development of secession conflicts (Sorens, 2012, pp. 112-138) and the promotion and protection of self-government agreements (Sorens, 2012, pp. 139-152). In fact, this is one of the core expectations of the republican tradition concerning factional conflicts: Whenever they are channelled through institutional devices that force all sides to consider the rival factions' interests and views, then peace and stability follow.

One possible answer to these five unresolved issues is considering them as actually unsolvable, at least in theoretical terms. What is a clear majority and even a clear question can vary in time; the borders of an independent Quebec would be one of the issues at stake in a post- "Yes" victory negotiation, and so on. In fact, this seems to be the approach of the Supreme Court of Canada: There is no option but to leave the resolution of all these issues to the political actors. However, if we are going to deal with these issues on a contextual basis, then it is imperative to know who would be the arbiter that would eventually monitor the resolution of them. Here, the Quebec Secession Reference remains as silent as on the other five issues. And here we have the sixth and final unresolved issue.

Unsurprisingly, soon after the Reference was issued, it became a new matter of controversy between Ottawa and Quebec. Thus, in 2000, the Parliament of Canada passed the so-called Clarity Act, which put into the House of Commons the power to assess the clarity of the question in a referendum on secession before the vote, as well as the power to assess the clarity of the "Yes" majority (had the "Yes" won) after the vote. The Clarity Act also required the inclusion of Aboriginals in the negotiations, which were potentially leading to secession, and stated that Quebec's secession would require an amendment of the Canadian constitution. In Quebec, both federalists and sovereigntists denounced the Clarity Act (Gagnon \& Hérivault, 2008, p. 178). Thus, two days later, the National Assembly of Quebec passed the so-called Bill 99, which gave the people of Quebec (presumably, through its representatives in the National Assembly) the sole power to unilaterally define how to exercise their right to decide their political status, as well as setting the threshold for a clear "Yes" victory at 50 percent of the votes plus one.

So the Canadian Parliament defined itself as the arbiter of any new Quebec referendum on independence, both in its process and its results, while the National Assembly of Quebec claimed this role for itself. So, in the end, it seems that the Reference just returned the problem to its starting point: to the impossible task of locating the "subject of sovereignty." The greatness of the Reference was, precisely, that it refused to choose a winner on a who-is-the-sovereign controversy, and thus it avoided running into the normative cul de sac in which all claims of sovereignty fall when we try to use them in order to manage secession controversies; it preferred, instead, to force both sides to democratically compete and, eventually, negotiate.

Unfortunately, by prescribing a sequence of competition and negotiation while avoiding a clear definition of its arbiter, the Court left those five previous issues 
not only unresolved but also unresolvable; at least, if we want their resolution not to rely on a "might makes right" logic, whose removal made the Reference interesting (in democratic republican terms) in the first place. In my view, this round-trip journey is caused by the fact that the Reference, while designing a useful anti-domination firewall based on a recognition of a "soft" right of secession for Quebec, is nevertheless limited to the framework of the Canadian constitution: National constitutionalism does not discuss who is the sovereign, but takes it for granted; therefore, when it is applied to secession conflicts, it easily leads to who-is-the-sovereign controversies. Thus, the Reference leaves us, in the end, face to face with precisely the controversy that the Court wisely decided to not resolve in favour of any of the parties involved. So it seems that, in terms of preventing domination, exclusion, and instability in any secession conflict, the Reference designs the right device, though placing it in a problematic locus.

\section{Conclusion}

The opening question of this article was: To what extent can a constitutional right of secession be useful in order to minimise exclusion and domination (understood in democratic republican terms) stemming from secession conflicts in modern democracies? Through an examination of the Quebec Secession Reference, I have come to the conclusion that (a) the constitutional right of secession outlined in the Reference is a useful device in democratic republican terms, due to its non-unilateralist spirit, and that (b) it nevertheless left open a series of unresolved issues in need of an arbiter, with Quebec and Ottawa fighting to assume this role. Thus, we find that a constitutional right of secession, at least in the case of Quebec, seems to be a firewall against domination, albeit an imperfect one. However, this is not a reason to reject it: in the absence of a better alternative, this imperfect firewall is, indeed, much better than no firewall at all. Therefore, a republican theory of secession should take its example into account.

\section{Acknowledgments}

This article is a result of my PhD research. In this sense, first and foremost, I would like to thank Ferran Requejo for his thorough supervision during the whole process at the Universitat Pompeu Fabra, as well as Alain-G. Gagnon for his mentoring during my research stay at the Université du Québec à Montréal, which was crucial for the development of this article. I would also like to thank the insights I received from Marc Sanjaume-Calvet, Adam Holesch, Peter A. Kraus, Klaus-Jürgen Nagel, Jaume López, Camil Unugureanu, Ivan Serrano, and Fernando Gil-Porquet while I was writing this article, as well as the useful feedback I got from Neus Torbisco Casals, Daniel Weinstock, and Rainer Bauböck when I finished its first version. I would also like to express my gratitude to the Spanish Ministry of Education, Culture and Sport for funding during the four years of research that resulted, among other outcomes, in this article.

\section{Conflict of Interests}

The author declares no conflict of interest.

\section{References}

Aronovitch, H. (2006). Seceding the Canadian way. Publius: The Journal of Federalism, 36(4), 541-564.

Bauböck, R. (2008). Normative political theory and empirical research. In D. della Porta \& M. Keating (Eds.), Approaches and methodologies in the social sciences. A pluralist perspective (pp. 40-60). Cambridge University Press.

Bellamy, R. (2007). Political constitutionalism: A Republican defence of the constitutionality of democracy. Cambridge University Press.

Buchanan, A. (2007). Justice, legitimacy, and selfdetermination. Oxford University Press.

Corlett, J. A. (1998). The morality and constitutionality of secession. Journal of Social Philosophy, 29(3), 120-128.

Dion, S. (1995). The dynamic of secessions: Scenarios after a pro-separatist vote in a Quebec referendum. Canadian Journal of Political Science, 28(3), 533-551.

Gagnon, A.-G., \& Hérivault, J. (2008). La reconnaissance irrésolue du Québec [The unresolved recognition of Quebec]. In A.-G. Gagnon (Ed.), D'un référendum à l'autre: Le Québec face à son destin [From one referendum to another: Quebec facing its destiny] (pp. 169-190). Presses de l'Université Laval.

Jovanovic, M. (2007). Constitutionalising secession in federalized states. A procedural approach. International Specialized Book Services.

Norman, W. (2003). Domesticating secession. In S. Macedo \& A. Buchanan (Eds.), Secession and selfdetermination (pp. 193-237). New York University Press.

Norman, W. (2006). Negotiating nationalism: Nationbuilding, federalism, and secession in the multinational state. Oxford University Press.

Pérez-Lozano, L. (2021). Theories of the right of secession: A republican analysis. Las Torres de Lucca. Revista Internacional de Filosofía Política, 10(18), 27-35.

Pettit, P. (1997). Republicanism: A theory of freedom and government. Oxford University Press.

Requejo, F. (2005). Multinational federalism and value pluralism: The Spanish case. Routledge.

Rokkan, S., \& Urwin, D. W. (1983). Economy, territory, identity: Politics of West European peripheries. SAGE.

Sartori, G. (2005). Parties and party systems. A framework for analysis. ECPR Press.

Sauvageau, F., Schneiderman, D., \& Taras, D. (2005). The last word: Media coverage of the Supreme Court of 
Canada. University of British Columbia Press.

Schertzer, R. (2016). The judicial role in a diverse federation: Lessons from the Supreme Court of Canada. University of Toronto Press.

Shaw, W. F., \& Albert, L. (1980). Partition: The price of Quebec's independence. Thornhill.

Skinner, Q. (1998). Liberty before liberalism. Cambridge University Press.

Sorens, J. (2012). Secessionism. Identity, interest, and strategy. McGill-Queen's University Press.

Sunstein, C. R. (1991). Constitutionalism and secession. The University of Chicago Law Review, 58(2), 633-670.

Sunstein, C. R. (2001). Should constitutions protect the right to secede? A reply to Weinstock. Journal of Political Philosophy, 9(3), 350-355.

Supreme Court of Canada. (1998). Reference re secession of Quebec.

Weinstock, D. (2000). Toward a proceduralist theory of secession. Canadian Journal of Law and Jurisprudence, 13(2), 251-262.

Weinstock, D. (2001). Constitutionalising the right to secede. Journal of Political Philosophy, 9(2), 182-203.

Woehrling, J. (2000). The Supreme Court's ruling on Quebec's secession: Legality and legitimacy reconciled by a return to constitutional first principles. In H. Mellon \& M. Westmacott (Eds.), Political dispute and judicial review (pp. 83-101). Nelson.

Young, R. A. (1998). A most politic judgment. Constitutional Forum, 10(1), 14-18.

Young, R. A. (1999). The struggle for Quebec. McGillQueen's University Press.

\section{About the Author}

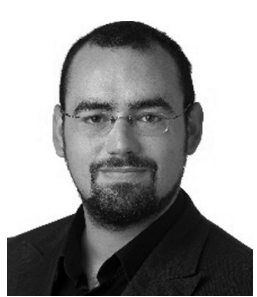

Lluís Pérez-Lozano is an adjunct professor at the Department of Political and Social Sciences, Universitat Pompeu Fabra, as well as a member of its Political Theory Research Group. His research interests are theories of democracy and justice, with a special focus on republicanism-its theoretical traits, its origins and evolution, its variants, and its possibilities and weaknesses in dealing with normative issues in modern democracies. 